Баган А. В., Юрченко С. О., кандидати сільськогосподарських наук, Шакалій С. М., аспірант*

Полтавська державна аграрна академія

\title{
МІНЛИВІСТЬ ПОТОМСТВА РІЗНИХ МОРФОЛОГІЧНИХ ЧАСТИН КОЛОСА СОРТІВ ПШЕНИЦІ ОЗИМОЇ ЗА КІЛЬКІСНИМИ ОЗНАКАМИ
}

Рецензент - доктор сільськогосподарських наук, професор В. М. Писаренко

Досліджено кількісні ознаки у сортів пшениці м'якої озимої за потомством верхньої, середньої й нижньої частин колоса. Встановлено рівень варіювання довжини колоса, кількості колосків $і$ зерен із колоса, маси колоса з насінням, маси зерен із колоса та маси 1000 зерен за потомством різних морфологічних частин колоса у досліджуваних сортів. Відмічено ефективність добору генотипів пшениці м'якої озимої за довжиною колоса $i$

кількістю колосків у ньому. Виділено потомство середньої частини колоса сортів пшениці озимої за продуктивністю та низьким рівнем варіювання кількісних ознак.

Ключові слова: пшениия озима, сорт, потомство, морфологічні частини колоса, кількісні ознаки, мінливість, коефіцієнт варіації.

Постановка проблеми. Кількісні ознаки характеризують найбільш важливі показники культурних рослин, у тому числі величину та якість врожаю. Водночас у генетичному відношенні вони вивчені ще недостатньо, хоч інформація цього напряму широко представлена в дослідженнях багатьох науковців. Дані ознаки характеризуються значною мінливістю й залежністю від факторів зовнішнього середовища. Їхнє вивчення потребує значної вибірки, яку отримують шляхом неабияких затрат часу і праці [1].

Головним напрямом селекції пшениці озимої $\epsilon$ підвищення продуктивності. Врожайний потенціал сорту завжди використовується як найважливіша його характеристика, тому дослідження елементів продуктивності за їх впливом на врожайність проводиться вже тривалий час.

Тому створення сортів пшениці з максимально можливим рівнем продуктивності $€$ кінцевою метою кожного селекціонера, поскільки збільшення урожайності - одне 3 найскладніших завдань, пов'язане зі значною його складністю і комплексністю.

Аналіз основних досліджень і публікацій, у яких започатковано розв'язання проблеми.
За останні 90 років висота рослин зменшилася на 35-40 сантиметрів. Внаслідок цього число зерен iз рослини збільшилося на $60 \%$. Отже, підвищення урожайності передусім зумовлене відповідною зміною кількості і маси зерен у рослинах.

Існує думка, що слід проводити добір за продуктивністю не рослини, а головного колоса, поскільки найчастіше ефект гетерозису спостерігається саме за довжиною колоса та деякими іншими кількісними ознаками. Важливим елементом продуктивності колоса $\epsilon$ його довжина. В генетичному плані довжина колоса - ознака, що добре успадковується [6].

Кількість колосків у колосі - найпластичніший елемент структури продуктивності, що залежить від екологічних умов, а також від особливостей росту і розвитку рослин на ранніх етапах органоутворення. Результати досліджень Ю. Б. Коновалова зі співавторами дали змогу встановити, що число колосків у колосі є одним із найголовніших елементів продуктивності рослини [3].

Важливим елементом продуктивності колоса $€$ число зерен у ньому. За даними П. П. Лук'яненка, конкретних кореляцій дана ознака 3 врожайністю не має. Проте окремі автори відмічають значну кореляційну залежність між числом зерен у колосі та врожайністю [4].

Маса зерна 3 колоса - важливий елемент продуктивності рослини. Вона залежить від багатьох факторів, зокрема довжини колоса, кількості зерен у ньому та їх крупності, а також від умов вирощування. В свою чергу маса зерна 3 колоса суттєво впливає на масу зерна 3 рослини та врожайність, оскільки між масою колоса та врожайністю існує позитивна кореляційна залежність [5].

Мета досліджень та методика їхнього проведення. Метою досліджень було встановлення мінливості потомства різних морфологічних частин колоса у сортів пшениці озимої за кількісними ознаками.

* Науковий керівник - доктор сільськогосподарських наук, професор Г. П. Жемела 
Матеріалом для досліджень було п'ять сортів пшениці м'якої озимої: Українка полтавська, Диканька, Говтва, С. Ковпак і Царичанка, у яких колос рослин був поділений на три частини верхню, середню і нижню. Кожну частину колоса рослин пшениці озимої було проаналізовано за кількісними ознаками, а насіння іiі п'яти рослин висіяне на відкритому майданчику тепличного комплексу Полтавської ДАА в оптимальні строки.

У досліджуваних сортів проведено за потомством кожної частини колоса структурний аналіз врожаю згідно із загальноприйнятою методикою, а саме: висоти рослини, товщини соломини, маси стебла, довжини колоса, кількості колосків і зерен у колосі, маси 1000 зерен, маси зерен із колоса та маси колоса 3 насінням. За результатами досліджень проведено статистичну обробку експериментальних даних за допомогою варіаційного аналізу за методикою Б. А. Доспєхова [2].

Результати досліджень. За середніми значеннями результатів досліджень виділено потомство середньої частини колоса сортів пшениці озимої. Так, за ознакою довжини колоса у досліджуваних сортів середнє значення варіювало у межах 8,2-8,4 см. Коефіцієнт варіації за даною ознакою був низьким (9,5-11,9 \%). У потомства середньої частини колоса спостерігалося найменше значення даного коефіцієнта, а в потомства верх- ньої частини колоса - найбільше.

За ознакою кількості колосків у колосі спостерігалася аналогічна ситуація: середнє значення даного показника становило 17,5-17,8 штук. Найбільшу кількість колосків у колосі відмічено у потомства середньої його частини. Дана ознака варіювала у межах 10,1-11,9 \% із найменшим коефіцієнтом варіації у потомства середньої частини колоса і найбільшим - у потомства верхньої його частини (див. табл.).

За середніми даними ознака кількості зерен у колосі у сортів пшениці озимої становила $34,1-$ 34,5 шт., а коефіцієнт варіації знаходився у межах 20,0-25,2 \%. Найбільшу кількість зерен у колосі мало потомства середньої частини колоса $(34,5$ шт.) із найменшим варіюванням даної ознаки (20,0\%).

Маса зерен із колоса у досліджуваних сортів становила 1,4-1,5 г, а коефіцієнт варіації становив 26,7-35,7 \%. Найбільшу масу зерен із колоса відмічено у потомства середньої й нижньої його частин $(1,5$ г), у якого також спостерігався найменший коефіцієнт варіювання $(26,7 \%)$, порівняно $з$ потомством верхньої частини колоса.

У маси колоса 3 насінням середнє значення даної ознаки становило 1,9 г, яка варіювала у межах 21,0-26,3 \%. Найменший коефіцієнт варіації мало потомства також середньої і нижньої частин колоса $(21,0 \%)$.

\section{Мінливість потомства різних морфологічних частин колоса сортів пшениці озимої за кількісними ознаками}

\begin{tabular}{|c|c|c|c|c|c|c|c|}
\hline Ознака & $\begin{array}{l}\text { Частина } \\
\text { колоса }\end{array}$ & $\mathrm{x} \pm \mathrm{Sx}$ & Min & Max & $S^{2}$ & $\mathrm{~S}$ & $\mathrm{~V}, \%$ \\
\hline \multirow{3}{*}{$\begin{array}{c}\text { Довжина } \\
\text { колоса, см }\end{array}$} & верхня & $8,4 \pm 0,1$ & 5,0 & 11,0 & 1,0 & 1,0 & 11,9 \\
\hline & середня & $8,4 \pm 0,1$ & 6,5 & 10,0 & 0,6 & 0,8 & 9,5 \\
\hline & нижня & $8,2 \pm 0,1$ & 6,5 & 10,0 & 0,7 & 0,8 & 9,8 \\
\hline \multirow{3}{*}{$\begin{array}{c}\text { Кількість } \\
\text { колосків } \\
\text { у колосі, шт. }\end{array}$} & верхня & $17,7 \pm 0,2$ & 10,0 & 21,0 & 4,3 & 2,1 & 11,9 \\
\hline & середня & $17,8 \pm 0,2$ & 14,0 & 22,0 & 3,4 & 1,8 & 10,1 \\
\hline & нижня & $17,5 \pm 0,2$ & 12,0 & 21,0 & 4,0 & 2,0 & 11,4 \\
\hline \multirow{3}{*}{$\begin{array}{c}\text { Кількість } \\
\text { зерен із колоса, } \\
\text { шт. }\end{array}$} & верхня & $34,1 \pm 0,9$ & 14,0 & 56,0 & 74,8 & 8,6 & 25,2 \\
\hline & середня & $34,5 \pm 0,8$ & 21,0 & 50,0 & 47,5 & 6,9 & 20,0 \\
\hline & нижня & $34,1 \pm 0,9$ & 15,0 & 48,0 & 53,4 & 7,3 & 21,4 \\
\hline \multirow{3}{*}{$\begin{array}{l}\text { Маса зерен } \\
\text { із колоса, г }\end{array}$} & верхня & $1,4 \pm 0,1$ & 0,4 & 2,7 & 0,2 & 0,5 & 35,7 \\
\hline & середня & $1,5 \pm 0,1$ & 0,8 & 2,5 & 0,2 & 0,4 & 26,7 \\
\hline & нижня & $1,5 \pm 0,1$ & 0,4 & 2,5 & 0,2 & 0,4 & 26,7 \\
\hline \multirow{3}{*}{$\begin{array}{l}\text { Маса колоса } \\
3 \text { насінням, г }\end{array}$} & верхня & $1,9 \pm 0,1$ & 0,7 & 3,1 & 0,3 & 0,5 & 26,3 \\
\hline & середня & $1,9 \pm 0,1$ & 1,2 & 2,8 & 0,2 & 0,4 & 21,0 \\
\hline & нижня & $1,9 \pm 0,1$ & 0,7 & 2,9 & 0,2 & 0,4 & 21,0 \\
\hline \multirow{3}{*}{$\begin{array}{c}\text { Мaca } 1000 \\
\text { зерен, г }\end{array}$} & верхня & $42,1 \pm 1,0$ & 19,0 & 67,8 & 82,7 & 9,1 & 21,6 \\
\hline & середня & $44,9 \pm 1,0$ & 28,2 & 66,7 & 75,7 & 8,7 & 19,4 \\
\hline & нижня & $43,4 \pm 1,0$ & 21,0 & 59,5 & 59,9 & 7,7 & 17,7 \\
\hline
\end{tabular}


Ознака маси 1000 зерен у сортів пшениці озимої становила 42,1-44,9 г, а коефіціснт варіації дорівнював 17,7-21,6 \%. За даною ознакою найменше варіювання відмічено у потомства нижньої частини колоса, а найбільше - у потомства верхньої його частини.

\section{Висновки:}

1. Найменше варіювання відмічено у потомства середньої частини колоса за довжиною $(\mathrm{V}=9,5 \%)$

\section{БІБЛІОГРАФІЯ}

1. Базалій В. В. Принципи адаптивної селекції пшениці озимої в зоні південного степу / В. В. Базалій. - Херсон : Айлант, 2004. - 244 с.

2. Доспехов Б. А. Методика полевого опыта / Б. А. Доспехов. - М.: Колос, 1985. - 336 с.

3. Коновалов Ю. Б. Изменение продуктивности колоса у озимой пшеницы в результате селекции / Ю. Б. Коновалов, В. В. Пыльнев, М. В. Пыльнев // Известия ТСХА. - М. : Колос, 1987.№ 4. - C. 47-54.

4. Лукьяненко П. П. Избранные труды / П. П. Лу- та за кількістю колосків у ньому $(\mathrm{V}=10,1 \%)$, що свідчить про ефективність добору генотипів за даними ознаками.

2. Встановлено, що з-поміж досліджуваних ознак у пшениці озимої добір буде знижуватися за масою зерен із колоса (V = 26,7-35,7 \%).

3. Виділено потомство середньої частини колоса за продуктивністю та низьким рівнем варіювання кількісних ознак.

кьяненко. - М. : Агропромиздат, 1990. - 428 с.

5. Михеев Л. А. О корреляции массы зерна с колоса с элементами его структуры у гибридов пшеницы / Л. А. Михеев // Селекция и семеноводство. - М. : Колос, 1992. - № 3. - С. 17-21.

6. Чекалин Н. М. Изменчивость признаков в популяциях озимой пшеницы в зависимости от типа и направления отбора / Н. М. Чекалин, Е. Г. Беляева // Селекция и семеноводство. - М. : Колос, 1986. - № 2. - С. 5-15. 